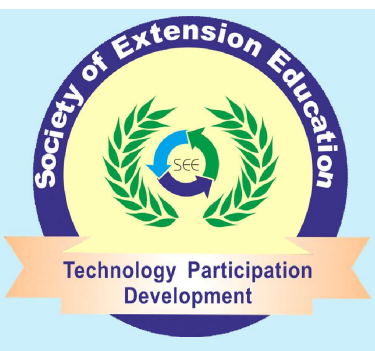

Research Note

\section{Indian Research Journal of Extension Education}

ISSN: 0972-2181 (Print), 0976-1071 (Online)

NAAS Rating : 5.22

Journal homepage: seea.org.in

https://doi.org/10.54986/irjee/2022/jan_mar/134-137

\title{
Impact of National Horticulture Mission on the Status of Beneficiary Farmers in Rajasthan District of India
}

\author{
Seema Yadav ${ }^{1}$, K.C. Sharma ${ }^{2}$, J.P. Yadav $^{3}$ and Vikas Kumar \\ 1\&4. Ph.D. Scholar and 2. Prof. and Head and 3. Prof., Department of Extension Education, \\ SKN College of Agriculture, SKNAU, Jobner, Jaipur (Rajasthan) India \\ Corresponding author e-mail : seemayadavsy91@gmail.com
}

Paper Received on August 28, 2021, Accepted on November 12, 2021 and Published Online on January 01, 2022

\begin{abstract}
India is mainly an agriculture-based country where majority of the people are engaged in agriculture. Diversified and boosted growth in agricultural is dependent upon the development of horticulture sector. Recognizing the importance of horticulture in stimulating the growth of Indian agriculture, government of India had launched NHM for the holistic development of this sector. NHM playing a important role in increase area as well as productivity of horticultural crops through motivation of farmers, providing guidance, subsidy and other facilities. It also plays an important role in improving the living standard of the farmers. It is a centrally sponsored scheme, launched by the Department of Agriculture \& Cooperation, Ministry of Agriculture, Government of India during 2005-06. Hence keeping the above facts in mind, the present study was conducted in 2020 to determine the socio-economic impact of NHM on the status of beneficiary farmers in Jaipur and Tonk districts of Rajasthan. A total of 240 beneficiary farmers were included in the sample of study. Study shows that NHM have positive impact with regard to occupation, annual income, saving pattern, expenditure, material possession, social development and employment generation of beneficiary farmers in the selected district. Thus, NHM improve overall socio-economic status of farmers.
\end{abstract}

Keywords: Socio-economic impact; National Horticulture Mission; Beneficiary farmers.

India is mainly an agriculture-based country where majority of the people are engaged in agriculture. Indian agriculture is an important factor for sustainable development and poverty alleviation. Even today agriculture sector is the main source of livelihood and food security major population in India. Horticulture has emerged as an important sector of diversification agriculture. It emerged as a growth engine of agriculture and making a significant contribution to agricultural GDP. Diversified and boosted growth in agricultural is dependent upon the development of horticulture sector. It plays a pivotal role in improving the productivity of land, generating employment, enhancing exports and improving the socio-economic status of the farmers.

Recognizing the importance of horticulture in stimulating the growth of Indian agriculture, government of India had launched a scheme of National Horticulture Mission for the holistic development of this sector. It is a centrally sponsored scheme, launched by the Department of Agriculture \& Cooperation, Ministry of Agriculture, Government of India during 2005-06. NHM plays a crucial role in promoting growth in horticulture and helps in augmenting growth in Indian agriculture. NHM playing a important role in increase in area as 
well as productivity of horticultural crops through motivation of farmers, providing subsidy, guidance and other facilities. It also plays an important role in improving the living standard of the farmers. NHM scheme includes production and productivity improvement of horticulture crops by supplying quality planting material, nurseries, rejuvenation of senile orchards, protected cultivation, cold storage facilities, integrated nutrient management, integrated pest management, production of organic farming and deploying honeybees for enhancing productivity through cross pollination. It is always important to find out the socioeconomic impact of NHM on its beneficiary farmers.

\section{METHODOLOGY}

Semi-arid Eastern Plain (IIIA) Agro Climatic Zone was selected for the study purpose. This Agro Climatic Zone comprises of four districts viz., Jaipur, Ajmer, Tonk and Dausa. Out of these Jaipur and Tonk districts were selected for the research study on the basis of maximum number of beneficiary farmers under selected activities of NHM. From Jaipur district 6 tehsils were selected viz., Amber, Chomu, Shahpura, Jhotwara, Sambhar and Bassi. From Tonk district also 6 tehsils were selected viz., Newai, Malpura, Tonk, Uniara, Todaraisingh and Deoli, those having maximum number of beneficiaries under selected activities of NHM. A list of beneficiary farmers under selected activities of NHM (farmers benefited from the year 2014 to 2016) from selected tehsils were prepared. From that list 30 per cent of beneficiary farmers were selected by using simple random sampling in proportionate from each tehsil and selected activities under NHM. These activities were selected on the basis of highest number of farmers taking benefits under NHM. Thus, a total of 240 beneficiary farmers were included in the sample of study. The investigator collected data by using personal interview method. The collected data were analyzed by using Mean Percent Score (MPS), Standard Deviation (S.D.) and $\mathrm{Z}$ test statistical method.

\section{RESULTS AND DISCUSSION}

Socio-economic impact of NHM on the status of beneficiary farmers : To know the socio-economic impact of NHM on the status of beneficiary farmers, ' $Z$ ' test was carried out and results were presented in the following sub-heads.
Occupational change before and after adoption of $N H M$ : Table 1 reveals that adoption of NHM in Jaipur ('Z'value 17.350) and in Tonk (Z' value 17.464) districts, was found significant. It might be because of the fact that NHM provided additional occupation for beneficiary farmers like flower production, dairy unit, poultry production, apiculture, traditional occupation etc. These findings are supported by Mankar et al. (2013), Rathod and Damodhar (2015) and Singh et al. (2018).

Annual income change before and after adoption of NHM : Table 1 shows that after adoption of NHM scheme in study area was found significant. Level of significance indicating that there is a significant difference in annual income of beneficiary farmers before and after adoption of NHM in Jaipur and in Tonk district. It might be because of the fact that before adoption of NHM, the main source of income of beneficiaries was from traditional crop cultivation like cereals and fodders. However, total income of the beneficiary farmers was not enough to fulfill their basic needs. After adoption of NHM, the activity like protected cultivation, fruit processing units, flower cultivation, fruit production etc. acted as main source of beneficiary farmer's occupation and gave more income to beneficiary farmers. These findings are supported by Raut (2016), Singh et al. (2018) and Singh et al. (2019).

Saving pattern change before and after adoption of NHM : Table 1 reveals that NHM scheme in Jaipur (' $Z$ ' value 12.814) and Tonk (' $Z$ ' value 11.517) districts was found significant. It could be stated that the beneficiary farmers significantly differed in their saving pattern before and after adoption of NHM. It means that NHM helped the beneficiary farmers to increase their saving. These findings are supported by Harish et al. (2011) and Pandya et al. (2015).

Expenditure change before and after adoption of $N H M$ : Table 1 shows that the expenditure change before and after adoption of NHM was found significant (' $Z$ ' value 18.017) in Jaipur district and in Tonk district (' $Z$ ' value 14.684). This change of beneficiary farmers to increase investment on expenditure after adoption of NHM might be due to the increase in income due to employment generation. It was observed from the data that, strong expenditure changes observed after adoption of NHM. These findings are supported by 
Table 1. Comparative difference in socio-economic changes in beneficiary farmers before and after adoption of $\mathrm{NHM}(\mathrm{N}=\mathbf{2 4 0})$

\begin{tabular}{|c|c|c|c|c|}
\hline \multirow{2}{*}{ Category } & \multicolumn{2}{|c|}{ Jaipur $\left(\mathrm{n}_{1}=140\right)$} & \multicolumn{2}{|c|}{ Tonk $\left(\mathrm{n}_{2}=100\right)$} \\
\hline & Before & After & Before & After \\
\hline \multicolumn{5}{|c|}{ Occupational change } \\
\hline Total & 140 & 140 & 100 & 100 \\
\hline Mean & 9.93 & 12.07 & 11.70 & 13.89 \\
\hline SD & 1.34 & 2.88 & 1.14 & 2.23 \\
\hline 'Z' value & \multicolumn{2}{|c|}{$17.350 * *$} & \multicolumn{2}{|c|}{$17.464 * *$} \\
\hline \multicolumn{5}{|c|}{ Annual income } \\
\hline Total & 140 & 140 & 100 & 100 \\
\hline Mean & 11.43 & 13.36 & 11.58 & 13.37 \\
\hline $\mathrm{SD}$ & 1.31 & 2.89 & 1.12 & 2.22 \\
\hline 'Z' value & \multicolumn{2}{|l|}{$14.321 * *$} & \multicolumn{2}{|c|}{$14.356^{* *}$} \\
\hline \multicolumn{5}{|c|}{ Saving pattern } \\
\hline Total & 140 & 140 & 100 & 100 \\
\hline Mean & 9.35 & 11.15 & 10.21 & 11.32 \\
\hline $\mathrm{SD}$ & 1.68 & 2.86 & 00.96 & 1.66 \\
\hline 'Z' value & \multicolumn{2}{|c|}{$12.814^{* *}$} & \multicolumn{2}{|c|}{$11.517^{* *}$} \\
\hline \multicolumn{5}{|c|}{ Expenditure pattern } \\
\hline Total & 140 & 140 & 100 & 100 \\
\hline Mean & 8.80 & 10.82 & 8.69 & 10.5 \\
\hline $\mathrm{SD}$ & 1.20 & 2.36 & 1.54 & 1.92 \\
\hline 'Z' value & \multicolumn{2}{|c|}{$18.017 * *$} & \multicolumn{2}{|c|}{$14.684^{* *}$} \\
\hline \multicolumn{5}{|c|}{ Material possession } \\
\hline Total & 140 & 140 & 100 & 100 \\
\hline Mean & 8.85 & 10.26 & 10.25 & 11.89 \\
\hline SD & 1.80 & 1.82 & 0.91 & 1.67 \\
\hline 'Z’ value & $12.950 * *$ & $17.191 * *$ & & \\
\hline \multicolumn{5}{|c|}{ Social development } \\
\hline Total & 140 & 140 & 100 & 100 \\
\hline Mean & 12.90 & 14.88 & 12.90 & 14.84 \\
\hline SD & 1.96 & 2.37 & 1.76 & 2.60 \\
\hline 'Z' value & $15.242 * *$ & & $12.355^{*}$ & \\
\hline \multicolumn{5}{|c|}{ Employment generation } \\
\hline Total & 140 & 140 & 100 & 100 \\
\hline Mean & 11.55 & 13.52 & 12.21 & 14.08 \\
\hline SD & 1.61 & 2.50 & 1.02 & 2.14 \\
\hline 'Z' value & $13.220 * *$ & & $15.712^{*}$ & \\
\hline \multicolumn{5}{|c|}{ Overall socio-economic status } \\
\hline Total & 140 & 140 & 100 & 100 \\
\hline Mean & 72.64 & 86.08 & 77.54 & 89.89 \\
\hline $\mathrm{SD}$ & 5.57 & 8.80 & 4.46 & 8.85 \\
\hline 'Z' value & $30.521 * *$ & & $24.905^{*}$ & \\
\hline
\end{tabular}

** Significant at 1 per cent level of significance
Godara (2011), Pandya et al. (2015) and Singh et al. (2018).

Material possession change before and after adoption of NHM : To find out the material possession change before and after adoption of NHM from Table 1 was found significant (' $Z$ ' value 12.950) in Jaipur and Tonk districts (' $Z$ ' value 17.191). These findings are supported by Parhad (2011), Bhandari (2014) and Raut (2016).

Social development change before and after adoption of NHM : Table 1 reveals that adoption of NHM scheme was found significant (' $Z$ ' value 15.242) in Jaipur and Tonk district (' $Z$ ' value 12.355) had a significant difference in social development of the beneficiary farmers. It might be because of the fact that the participation of NHM beneficiary farmers in different social programmes, social activities like krishi mela, social campaign and various social organizations like Panchayat Samiti, Gram Panchayat, Zilla Parishad or any political party was increased due to NHM. These findings are supported by Uma (2014), Pandya et al. (2015), Meena et al. (2017) and Singh et al. (2018). Employment generation change before and after adoption of NHM : Table 1 reveals that NHM scheme increaseing the employment opportunities in the rural areas. It was It was observed from the above table that, strong employment generation changes observed after adoption of NHM. These findings are supported by Godara (2011), Venu Prasad (2012) and Meena et al. (2017).

Overall socio-economic impact of NHM : Table 1 was found significant at 1 per cent level of significance indicating that there is a significant difference in overall socio-economic impact on beneficiary farmers before and after adoption of NHM in Jaipur and in Tonk districts was found significant. It indicating that there is a significant difference in overall socio-economic impact on beneficiary farmers before and after adoption of NHM. It means that NHM helped the beneficiary farmers to increase their overall socio-economic status. These findings are supported by Bansode et al. (2013), Mankar et al. (2013), Pandya et al. (2015), Balkrishna (2016) and Sawant \& Mahadik (2018).

\section{CONCLUSION}

Study shows that NHM have positive impact with regard to occupation, annual income, saving pattern, 
expenditure, material possession, social development and employment generation of beneficiary farmers in the selected district. Thus, NHM improve overall socioeconomic status of farmers. Hence, the government needs to boost the growth of horticulture by covering more area under NHM programme with attractive subsidies to interested farmers. The farmers need to be encouraged to take up benefits from NHM in large areas. Even though NHM made lot of efforts to increases the income and employment opportunities to the beneficiaries but still the beneficiaries were facing some major constraints like, insufficient subsidy amount, lack of adequate information at right time, lack of awareness of NHM guidelines etc. Hence, NHM needs to take care of these problems and need to revise its policies accordingly

\section{CONFLICTS OF INTEREST}

The authors declare that they have no conflicts of interest.

\section{REFRENCES}

Balkrishna, A.G. (2016). Socio-economic impact of National Horticulture Mission on its beneficiaries in Marathwada region. Ph.D. Thesis, Department of Extension Education, Vasantrao Naik Marathwada Krishi Vidyapeeth, Parbhani (Maharashtra).

Bhandari, S.D. (2014). Socio-economic impact of Mahatma Gandhi National Rural Employment Guarantee Act on the beneficiaries. M.Sc. (Agri.) Thesis, Vasantrao Naik Marathwada Krishi Vidyapeeth, Parbhani (Maharashtra).

Bansode, S.M.; Ankush, G.S.; Mande, J.V. and Suradkar, D.D. (2013). Impact of SHG on socio-economic development of their members. Journal of Community Mobilization on Sustainable Development. 8 (11), 117-120.

Godara, R.K.; Panth, D.C. and Burark S.S. (2011). Impact of Integrated Village Development Project (IVDP) on income consumption and employment in tribal area of southern Rajasthan. Indian Journal of Extension Education. 47 (1 \& 2), 70-74.

Harish, B.G.; Nagaraj, N.; Chandrakanth, M.G.; Shrikantha, M.; Chengappa, P.G. and Basavaraj, G. (2011). Impact and implication of MGNREGA on labour supply and income generation for agriculture in central dry zone of Karnataka. Agricultural Economics Research Review (24), 485-494.

Mankar, D.M.; Wankhade, P.P. and Shambharkar, V.B. (2013). Impact of National Horticulture Mission on its beneficiaries. International journal of Extension Education. 9, 72-80.

Meena, G.L.; Upadhyay, B. and Singh, H. (2017). Impact of Livelihood and Nutritional Security Project on socio-economic status of rural households in Udaipur district of Rajasthan. Indian journal of Extension Education \& Rural Development. 25, 9-14.

Pandya, S.P.; Prajapati, M.R. and Thakar, K.P. (2015). Socio-economic impact of Krishi Mahotsav on beneficiary farmers of Gujarat. Indian Journal of Extension Education. 51 (1/2), 75-77.

Parhad, A.R. (2011). Impact of Mahatma Gandhi National Rural Employment Guarantee Scheme on the beneficiaries. M.Sc. (Agri.) Unpublished Thesis, Mahatma Phule Krishi Vidyapeeth, Rahuri (Maharashtra).

Rathod, M.K. and Damodhar, P. (2015). Impact of MAVIM activities on empowerment of rural women. Indian Research Journal of Extension Education. 15 (1), 8-11.

Raut, H.R.; Prajapati, R.R.; Prajapati, M.D. and Prajapati, M.R. (2016). Socio-economic impact of Self Help Group on members in Banaskantha district of Gujarat. Indian Journal of Extension Education. 51 (1\&20), 88-91.

Sawant, P.A. and Mahadik, R.P. (2018). Socio-economic impact of mango technologies developed by Dr. BSKKV, Dapoli on farmers. Indian Journal of Extension Education \& Rural Development. 26, 150-154.

Singh, A.; Singh, K.; Singh, M.; Singh, A.K. and Bagri, R. (2018). The socio-economic impact of Women Farmer's Interest Group on lac growers. Indian Journal of Extension Education. 54 (4), 106-111.

Singh, D.; Singh, A.; Singh, R. and Baghel, M.S. (2019). Impact of FLDs intervention on yield and economics of paddy cultivation. Indian Journal of Extension Education. 55 (1), 164-167.

Uma, Prasher (2014). Mahatma Gandhi National Employment Guarantee Act and its impact on the beneficiaries. Asian Journal of Research in Social Sciences and Humanities. 4(4), pp: 50-60.

Venu, Prasad; H.D.; Singh, P. and Chaturvedi, V.K. (2012). Socio-economic impact analysis of contract farming of gherkin in Karnataka. Indian Journal of Extension Education. 48 (1\&2), 42-44. 